\title{
Perkembangan Bahasa pada Anak Speechdelay
}

\author{
Jauharoti Alfin ${ }^{1}$, Ratna Pangastuti ${ }^{2}$ \\ ${ }^{1,2}$ UIN Sunan Ampel Surabaya
}

\begin{abstract}
DOI : https://doi.org/10.15642/jeced.v2i1.572

\begin{tabular}{|c|}
\hline Abstract \\
\hline $\begin{array}{l}\text { Language development in early childhood is very important for the continuity } \\
\text { of his life as a social creature. Incoming language skills have an aspect of } \\
\text { early childhood development. This article seeks to discuss the development } \\
\text { of speech-based children's language in theory by analyzing documented cases } \\
\text { of published research results. The research method used is a library research } \\
\text { with content analysis for the discussion technique. Source of data taken from } \\
\text { secondary data from research results in thesis or online journals, then } \\
\text { combined with several existing theories. Based on the results of the } \\
\text { discussion obtained data that children with speech delay will experience } \\
\text { language delays both in terms of articulation, sound, fluency and } \\
\text { completeness of the preparation of the letters. Many factors as a trigger that } \\
\text { is external and internal. Most of the cases that have external factors in the } \\
\text { form of parenting are the dominant factors in children experiencing speech } \\
\text { delay. Mild speechdelay children can recover with appropriate meode } \\
\text { stimulation and selection, while children with medium and large speechdays } \\
\text { need the help of experts (therapists) and medical personnel }\end{array}$ \\
\hline Abstrak \\
\hline $\begin{array}{l}\text { Perkembangan bahasa pada anak usia dini sangat penting untuk } \\
\text { keberlangusngn hidupnya sebagai makhluk sosial. Kemampuan berbahasa } \\
\text { masuk ada aspek perkembangan dasar anak usia dini. Artikel ini berusaha } \\
\text { membahas perkembangan bahasa anak speechdelay secara teori dengan } \\
\text { menganalisis kasus-kasus yang terdokumentasi dari hasil-hasil riset } \\
\text { terpublikasi. Metode riset yang digunakan adalah casse study dengan content } \\
\text { analysis untuk teknik pembahasannya. Sumber data diambil dari data } \\
\text { sekunder hasil riset di skripsi atau jurnal online, kemudian dipadukan dengan } \\
\text { beberapa teori yang ada. Berdasarkan hasil pembahasan diperoleh data bahwa } \\
\text { anak dengan speechdelay akan mengalami gangguan keterlambatan } \\
\text { berbahasa baik dari segi artikulasi, suara, kefasihan maupun kelengkapan } \\
\text { penyusunan huruf-hurufnya. Banyak faktor sebagai pemicunya yaitu } \\
\text { eksternal dan internal. Kebanyakan dari kasus yang ada faktor eksternal } \\
\text { dalam bentuk pola asuh yang menjadi faktor dominan anak mengalami } \\
\text { speechdelay. Anak speechdelay ringan dapat sembuh dengan stimulasi dan } \\
\text { pemilihan meode yang tepat, sedangkan anak dengan speechdelay sedang dan } \\
\text { besat dibutuhkan bantuan tenaga ahli (terapis) dan tenaga medis. }\end{array}$ \\
\hline
\end{tabular}
besat dibutuhkan bantuan tenaga ahli (terapis) dan tenaga medis.
\end{abstract}

\section{Article Info}

Article history:

Received: 13062020

Accepted: 14062020

Published online: 15062020

\section{Keywords:}

learning model

early childhood

askerelectronic media.

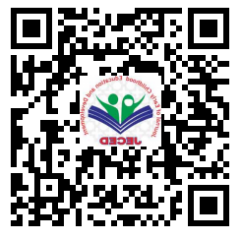

\section{Informasi Artikel \\ Riwayat Artikel}

Revisi terakhir: 13062020

Diterima: 14062020

Publikasi online: 15062020

\section{Kata kunci:}

Perkembangan Bahasa anak speechdelay 


\section{PENDAHULUAN}

Bidang pengembangan bahasa dalam Standar Tingkat Pencapaian Perkembangan Anak Usia Dini dikategorikan menjadi bahasa reseptif, bahasa verbal, dan keaksaraan. Pengembangan bahasa melibatkan asapek sensori motor terkait dengan kegiatan mendengar, kecakapan memahami, dan produksi suara (Meitsari Tjandrasa, 2013:176). Dalam jurnal Komunikasi, "Komunikasi Reseptif dalam Meningkatkan Prestasi Belajar Anak" menjelaskan bahwa komunikasi dibedakan menjadi dua yaitu komunikasi reseptif dan komunikasi produktif, adapun yang dimaksud dengan bahasa reseptif terdiri atas menyimak dan membaca, sedangkan komunikasi produktif terdiri atas berbicara dan menulis. Dilihat dari tujuannya, komunikasi reseptif lebih mesifat tindakan satu arah artinya terjadi proses penyampaian pesan secara langsung atau melalui media dari komunikator kepada komunikan, sedangkan untuk komunikasi produktif bersifat timbal balik atau interaktif (Adiwiria, 2007:2). Jurnal Pendidikan Khusus, "Pelaksanaan Pengembangan Kemampuan Bahasa Reseptif dan Bahasa Ekspresif Anak Tunarungu kelas TK 1A" menjelaskan yang dimaksud bahasa reseptif adalah kecakapan menerima dan memahami bahasa (Fatimah, 2012:50). Dari beberapa penjelasan tentang bahasa reseptif diatas, dapat disimpulkan bahwa bahasa reseptif adalah kemampuan seorang anak dalam menerima informasi dari berbagai sumber baik yang diperolehnya melalui penglihatannya, pendengarannya, maupun perabaannya. Artinya anak yang memiliki kemampuan untuk berbahasa reseptif adalah mereka yang mengerti apa yang diterimanya melalui panca indera. Dari empat aspek dalam berbahasa yaitu menyimak, berbicara, membaca, dan menulis (Bromley, 1992), maka bahasa reseptif tetap mengandung keempat aspek tersebut namun lebih kepada proses penerimaan secara pasif.

Anak memperoleh bahasa pertama kali dari lingkungan keluarganya. Mereka mulai mendengar dan mengenal bahasa pertama dari keluarganya bahkan belajar berbicara. Keluargalah sebagai faktor eksternal bagi anak dalam menentukan proses kemampuan mereka dalam memperoleh bahasa, bagaimana keluarga tersebut menstimulasi kemampuan bahasa anak-anak mereka terutama dalam masa pertumbuhan dan perkembangan. Ketika keluarga tidak maksimal dalam menstimulasi perkembangan bahasa anak-anaknya maka akan berakibat kemampuan anak tersebut mengalami keterlambatan dan kemampuan komunikasi terhambat.

Dalam jurnal Ilmiah Mahasiswa Pendidikan Anak Usia Dini vol. 1 no. 1 Agustus 2016 hal 38, Khoiriyah menjelaskan anak yang terlambat berbicara akan mengalami gangguan dalam penyampaian bahasa secar verbal sedangkan untuk kemampuan reseptifnya sudah memadai. Terlambatnya kemampuan berbicara anak juga dapat menyebabkan anak kesulitan dalam menyesuaikan diri dan bersosialisasi dengan lingkungan sekitar, akibatnya anak akan menarik diri dari lingkungan sekitar dan menjadi introvert. Ada sembilan faktor yang mempengaruhi perkembangan bicara anak diantaranya: kecerdasan, jenis kelamin, disiplin, posisi urutan anak, besaarnya keluarga, status ekonomi sosial, ras, berbahasa dua atau ganda (bilingual), suara yang sangat gaduh ( kebisingan), dan gaya bicara (Rumini, 2004:43-44). Menurut Hurlock (1978:186187), anak yang mengalami speechdelay dilatarbelakangi oleh faktor anak kembar dan jenis kelamin. Journal of American Family Doctor vol. 10 no. 83 tahun 201 halaman 1183 menuliskan keterlambatan bicara disebabkan kondisi lain seperti gangguan pendengaran, cacat intelektual, gangguan speaktrum autisme, masalah bicara fisik, atau mutisme selektif (gangguan kecemasan masa kanak-kanak yang ditandai oleh ketidakmampuan seorang anak untuk berbicara dan berkomunikasi secara efektif dalam situasi sosial). Permendikbud no. 137 tahun 2014, kemampuan anak menerima bahasa atau kominakasi reseptif meliputi kemampuan menyimak perkataan orang lain, mengerti dua perintah yang diberikan secara bersamaan, memahami cerita atau dongeng sederhana yang dibacakan.

Anak usia dini yang berada pada rentang usia 3 s.d 5 tahun memiliki kemampuan berbahasa yang berbeda. Ada yang mengalami terlambat bicara (speechdelay), kemampuan fokus lebih pendek, kemampuan merespon pertanyaan dengan cepat dan sebaliknya, belum mampu 
memahami perintah, kemampuan bercerita atau berbicara lebih banyak dari tingkatannya, dan lain sebagainya. Karena semua hal itu sebagai pertanda bahwa setiap anak adalah unik dan tumbuh kembang mengikuti irama kehidupannya masing-masing.

Prevalensi keterlambatan perkembangan berbahasa di Indonesia menurut kutipan dalam jurnal Kedokteran dan Kesehatan, vol. 2 no. 1 Januari 2015 hal 121-127 mengutip belum pernah diteliti secara luas. Data yang diperoleh dari Departemen Rehabilitasi Medik RSM Jakarta tahun 2006, dari 1125 jumlah kunjungan pasien anak terdapat 10, 13\% terdiagnosis mengalami keterlambatan bicara dan bahasa. Kemudian, sebuah penelitian yang dilakukan di rawat jalan THT-KL RS dr. Moh. Husein subdivisi Neurootologi dari Januari 2010 sampai dengan Maret 2012 didapat Populasi anak dengan keterlambatan bicara sebanyak 513 anak.

Artikel ini akan membahas secara teori pustaka tentang beberapa kasus perkembangan bahasa anak yang mengalami speechdelay pada rentang usia 3 s.d 5 tahun. Dalam kasus anak yang mengalami speechdelay, selain mereka mengalami hambatan dalam hal komunikasi verbal, juga mengalami hambatan komunikasi reseptif. Dan penulis akan fokus pada pembahasan kemampuan bahasa reseptif anak speechdelay di beberapa kasus pada hasil riset ilmiah di beberapa artikel ilmiah yang penulis dapatkan di website.

\section{METODE}

Dikarenakan dalam tulisan ini data yang diperoleh berupa data sekunder yang membahas tentang permasalahan bahasa reseptif anak speechdelay dalam bentuk dokumen hasil riset ilmiah di jurnal atau skripsi atau tesis atau disertasi yang ditemukan di website, maka metode penelitian yang dipilih adalah case study, dengan content analysis sebagai teknik analisanya.

\section{HASIL PENELITIAN DAN ANALISIS}

Ditemukan kasus pada hasil penelitian oleh Retno Ragil dalam skripsinya tahun 2019, terdapat sebuah lembaga usia dini informal di Surabaya yang menerima anak speechdelay, yaitu lembaga bimbingan minat baca dan belajar anak AIUEO atau lebih dikenal biMBA AIUEO. Lembaga yang berdiri sejak 1998 sekarang telah memiliki lebih dari 500 cabang diseluruh Indonesia. Metode pembelajaran yang dilakukan di biMBA adalah fun leaning, small step system, individual system dan variation skills. Lembaga ini menerapkan metode pembelajaran yang $100 \%$ harus menyenangkan bagi anak, dilaksanakan secara bertahap, dimulai dari yang paling mudah dan berupaya menumbuhkan minat anak terlebih dahulu agar anak nyaman dan tidak terbebani, fokus pada kemampuan individu anak yang unik dan variatif (Retno, 2019:64-66).

Dilembaga ini ada anak yang terindikasi speechdelay yaitu VV, usianya 5 tahun saat ini dan anak kedua dari dua saudara. Kakaknya sibuk sekolah sejak pagi hingga sore dan orangtuanya juga sibuk mengelola bengkel seharian, jarak antara VV dengan kakaknya 5 tahun sehingga komunikasi mereka kurang erat. Dirumah VV nyaris tidak ada teman ngobrol dan bermain, hanya bersama gadget dia habiskan waktu kesehariannya hingga berpengaruh pada perkembangan emosional sosialnya. Kecenderungannya ke gadget semakin lekat dan memunculkan reaksi tantrum ketika dipisah, kepribadian VV menjadi suka menutup diri dan menciptakan dunia sendiri baginya. Saat VV berusia 4 tahun 8 bulan, jenis gangguan artikulasi yang dialaminya. Ketika menyebut kata "badut" menjadi "aduk" dan kata "bola" menjadi "boa", kata "rambut" menjadi "wambut" dan sebagainya. Ketika mengucapkan kalimat "mama minta pulang" dia ucapkan "mama mita puan". (Retno, 2019:71-72)

Kasus kedua yang juga didapat dari hasil riset Retno (2019) adalah CY juga merupakan anak kedua dari dua bersaudara. CY sudah mengalami gangguan pendengaran sejak kecil, pada usia 12 bulan sudah bisa mengoceh secara normal namun lambat laun ketika usia 3 tahun mulai terlihat berrubahan pada perkembangan CY. CY mulai jarang kommunikasi dengan orang sekitar dan ketika diajak komunikasi cukup lama meresponnya. Bicaranya pelat atau cadel. Misalnya ketika 
ingin bicara "mama saya mau makan" dia ucapkan "mama aka", "mama usu" artinya "mama saya minum susu". Kemudian orangtuanya memeriksakan ke Rumah Sakit, dengan hasil pemeriksaan CY mengalami gangguan pendengaran konduktif hingga mengakibatkan suara yang didengar CY lebih pelan dari suara aslinya atau cenderung tidak jelas. Kasus keterlambatan berbahasa yang dialami CY lebih pada pengurangan huruf atau kata, misalnya kata "burung" diucapkan "burrrrrrrn", kata "tidak" menjadi "tidaaa", "tolong" diucapkan "tolonn" dan sebagainya. Ketika meminta mainan CY akan mengucapkan "tolonn main", ketika menolak sesuatu ia akan mengucapkan "tidaaa....tidaaa..." (Retno, 2019:75)

Kasus ketiga didapati pada anak laki-laki yang berinisial AA, merupakan anak ketiga dari tiga bersaudara yang rentang usia dengan kakaknya 4 tahun. Ayahnya wiraswsta dan ibunya dirumah yang sibuk dengan pekerjaan rumah dan mengasuh ketigsaat a anaknya. AA lebih suka tinggal dirumah dengan berteman gadget dan televisi. Ketika berada di sekolah dan ingin ke kamar mandi, AA hanya mengucapkan "Bu, pipis", untuk mengungkapkan keinginannya AA hanya menunjuk suatu benda dan mengucap satu atau dua kata, misal ingin buku hanya mengatakan, "buku" sambil menunjukkan benda buku yang diinginkan. Selain itu AA juga mengalami gangguan artikulasi dengan sering tertukar antara huruf, "G" dengan " $D$ ", huruf "J" dibaca " $D$ ", dan "K" dibaca "TA" serta yang lainnya.

\section{PEMBAHASAN}

Speechdelay adalah kondisi dimana anak usia dini mengalami keterlambatan proses berbicara dibandingkan dengan proses bicara anak seusianya. Jenis-jenis keterlambatan dalam berbicara pada anak usia dini menurut Van Tiel yaitu (a) Specific Language Impairment adalah gangguan bahasa primer yang disebabkan karena gangguan perkembangannya sendiri, tidak disebabkan oleh gangguan sensoris, neurologis, dan kognitif (intelegensi). Proses gangguan ini bisa terjadi akibat kesalahan pola asuh pada anak. (b) Speech and Language Expressive Disorder adalah gangguan pada bahasa ekspresi dalam proses pengutaraan bahasa oleh anak. Bentuk gangguan yang terjadi misalnya pada gangguan kefasihan dan artiklasi. (c) Centrum Auditory Processing Disorder adalah gangguan bicara yang tidak disebabkan karena masalah pada organ pendengarannya. Kondisi pendengarannya baik namun mengalami kesulitan dalam pemrosesan informasi yang tempatnya didalam otak. (d) Pure Dysphatic Development adalah gangguan perkembangan bicara dan bahasa ekspresif yang mempunyai kelemahan pada sistem fonetik atau penyampaian bahasa melalui ujaran. (e) Gifted Visual Spatial Learner adalah karakteristik yang dimiliki seorang individu dengan kemampuan yang uggul dalam bidang akademik dan memiliki tingkat kecerdasan IQ antara 125 s.d 140.

Perkembangan bahasa anak usia 3 sampai 4 tahun sudah mulai mampu memikirkan lingkungan sekitarnya dan mulai bersosialisasi. Mereka sudah mampu mengingat nama temantemannya dan mengucapkan kalimat sederhana 3 sampai 4 kata. Mereka mulai menyanakan banyak hal yang diperolehnya melalui penglihatannya dan pendengarannya kepada oarng dewasa. Hal ini juga didukung dengan rasa ingin tahunya yang besar sdah muncul. Sehingga orang dewasa harus sabar menjawab dan menerangkan tentang pertanyaan anak sesuai kemampuannya, jangan malah meyuruhnya diam dan menganggapnya cerewet sehingga mengharuskan anak tersebut diam. Hal ini akan berdampak negatif secara tidak langusng pada perkembangan bahasa anak selanjutnya dan psikologis, emosional sosialnya. Tahap perkembangan bahasa anak usia 4 sampai 5 tahun merupakan tahap akhir dimasa kanak-kanak, mereka sudah dapat berbicara menggunakan kalimat kompleks dengan jelas, dapat membedakan banyak sedikit, membedakan warna, menyebut nama hari dan bulan, mulai belajar bercerita. Mereka sudah mampu memberikan pendapat terhadap suatu kejadian yang dilihatnya dan didengarnya secara sederhana, mengajukan pertanyaan. 
Tingkat Pencapaian Perkembangan Anak berdasarkan Peraturan Menteri Pendidikan dan Kebudayaan nomor 137 tahun 2014 untuk kemampuan aspek bahasa anak usia 3 s.d 5 tahun dijelaskan dalam tabel dibawah.

Tabel 1. Ruang Lingkung Pengembangan Aspek Bahasa Anak Usia 3 s.d 5 Tahun

\begin{tabular}{ccc}
\hline Lingkup & \multicolumn{2}{c}{ Tingkat Pencapaian Perkembangan Anak } \\
\cline { 2 - 3 } Perkembangan & 3 s.d 4 tahun & 4 s.d 5 tahun \\
\hline
\end{tabular}

Bahasa

A. Memahami

Bahasa
1. Pura-pura membaca cerita 1. Menyimak perkataan orang lain bergambar dan dalam buku dengan kata-kata sendiri.

2. Mulai memahami dua perintah yang diberikan bersamaan contoh: ambil mainan diatas meja lalu berikan kepada ibu pengasuh atau pendidik.

(bahasa ibu atau bahasa lainnya).

2. Mengerti dua perintah yang diberikan bersamaan.

3. Memahami cerita yang dibacakan.

4. Mengenal perbendaharaan kata mengenai kata sifat (nakal, pelit, baik hati, berani, baik jelek, dsb)
5. Mendengarkan dan membedakan -bunyian dalam Bahasa Indonesia (contoh, bunyi dan ucapan harus sama)

B. Mengungkapkan 1. Mulai menyatakan keinginan 1. Mengulang kalimat sederhana Bahasa dengan mengucapkan kalimat sederhana (6 kata).

2. Mulai menceritakan pengalaman yang dialami dengan cerita sederhana.

2. Bertanya dengan kalimat benar.

3. Menjawab pertanyaan sesuai dengan pertanyaan.

4. Mengungkapkan perasaan dengan kata baik, senang, nakal, pelit, baik hati, berani, baik, jelek, dsb)

5. Menyebutkan kata-kata yang dikenal.

6. Mengutarakan pendapat kepada orang lain.

7. Menyatakan alasan terhadap sesuatu yang diinginkan atau ketidaksetujuan.

8. Menceritakan kembali cerita/dongeng yang pernah didengar.

9. Memperkaya perbendaharaan kata.

10. Berpartisipasi dalam percakapan.

C. Keaksaraan

1. Mengenal simbol-simbol.

2. Mengenal suara-suara hewan /benda

3. Membuat coretan yang bermakna.

4. Meniru (menuliskan dan mengucapkan) huruf A-Z 
National Institutes of Health secara umum menuliskan tahap perkembangan bahasa pada anak terpenting terjadi secara normal pada usia 0 sampai 5 tahun. Pada masa tumbuh kembang tersebut biasanya digunakan sebagai tolok ukur oleh para dokter atau ahli kesehatan untuk melihat apakah perkembangan bahasa pada anak tersebut normal ataukah memerlukan bantuan dari tenaga profesional. Beberapa indikasi anak memerlukan bantuan dari tenaga profesional dan perlakuan khusus seperti terjadinya speechdelay (keterlambatan berbicara), receptive language (sulit menangkap atau memahami ucapan orang lain) hingga difficulty sharing (sulit untuk menyampaikan pemikiran melalui bahasa).

Menurut Piaget dan Vygotsky (dalam Tarigan, 1988) tahap-tahap perkembangan bahasa anak disajikan dalam tabel berikut (Djuwarijah, 2007:24-25):

Tabel 2. Tahap Perkembangan Bahasa Anak menurut Piaget dan Vygotsky

\begin{tabular}{|c|c|}
\hline Usia & Tahap Perkembangan Bahasa \\
\hline 0,0 s.d 0,5 tahun & Meraban (pralinguistik) pertama \\
\hline 0,5 s.d 1,0 tahun & Meraban (pralinguistik) kedua: kata nonsense \\
\hline 1,0 s.d 2,0 tahun & Linguistik I : holofrastik; kalimat satu kata \\
\hline 2,0 s.d 3,0 tahun & Linguistik II : kalimat dua kata \\
\hline 3,0 s.d 4,0 tahun & Linguistik III : pengembangan tata bahasa \\
\hline 4,0 s.d 5,0 tahun & Linguistik IV : tata bahasa pra-dewasa \\
\hline 5,0 tahun s.d -- & Linguistik V : kompetensi penuh \\
\hline
\end{tabular}

Pada tahap linguistik III yaitu pengembangan tata bahasa, biasa dimulai sekitar usia 2,6 tahun ada yang masuk usai 2,0 namun ada juga yan terlambat ketika usia 3,0 tahun. Pada tahap ini anak-anak mulai menggunakan unsur-unsur bahasa yang rumit dengan struktur bahasa yang lebih rumit, misalnya; pola-pola kalimat sederhana, kata-kata tugas (di, ke, dari, ini, itu, dsb), penjamakan, pengimbuhan, terutama awalan dan akhiran yang mudah dan bentuknya sederhana (Hartati, 2000 dalam Djuwarijah, 2017). Walaupun demikian, kalimat-kalimat yang dihasilkan anak masih seperti bentuk telegram, misalnya; 'ini adi nani, kan?" disini kata "adi" bermaksud "adik", "mama pigi ke pasar", "mam mandi dulu", dan sebagainya. Mengapa pada tahap ini bahasa anak dilukiskan sebagai bahasa telegram? Karena pengetahuan kata-kata tugas masih terbatas, anak membuat pola pesan dengan kalimat pendek. Menurut Marat (1983) yang dihilangkan pada bahasa telegram biasanya berupa kata ganti orang (nya, mu, ku), kata kerja bantu (dengan baik, dengan cepat, dan lain-lain), kata sambung (dan, juga, serta, dan lain-lain), kata sandang (si, sang), kata bantu (akan, telah), kata depan (ini, itu, dan lain-lain), dan kata imbuhan (awalan dan akhiran).

Tahap linguistik IV atau tahap bahasa menjelang dewasa/pradewasa, yang biasa sudah dikuasa oleh anak-anak berusia 4 s.d 5 tahun. Pada tahap ini mereka mulai menerapkan struktur tata bahasa dan kalimat-kalimat yang agak lebih rumit, mereka sudah mempu menggunakan kalimat majemuk sederhana, contohnya: 'mau nonton sambil makan keripik', 'aku disini kakak disana', 'mama beli sayur dan kerupuk', 'aku lihat kakek dan nenek dijalan', 'ayo nyanyi dan nari', 'kakak adik dari mana'. Pada tahap ini pengucapan bunyi artikulasi pda anak normal sudah sempurna dan tidak mengalami kesulitan, walau sebagian kecil masih ditemukan pada anak kecil untuk kesulitan mengucapkan bunyi tertentu. Kesulitan yang dihadapi oleh anak pada tahap ini menurut Clark (1977) adalah cara memetakan ide ke dalam bahasa, dikarenakan mereka masih mengalami keterbatasan kosakata dan imbuhan, penguasaan struktur tata bahasa. Mereka cenderung masih sulit mengucapkan kata-kata yang tidak keluar dari nuraninya, akan tetapi mereka memiliki potensi untuk senang mempelajari sesuatu karena sifat alamiahnya "coriusity", dan lambat laun akhirnya dapat mempelajari bahwa jika bersalah harus meminta maaf dan 
mengucapkan terima kasih ketika mendapatkan sesuatu dari orang lain atau mendapat bantuan dari orang lain, atau mengucapkan minta tolong ketika menginginkan bantuan dari orang lain.

Tahap linguistik V atau kompetensi penuh yaitu tahap untuk anak-anak berusia 5 s.d 7 tahun. Sejak usia 5 tahun secara normal perkembangan anak telah menguasai unsur-unsur sintaksis bahasa ibunya dan telah memiliki kompetensi bahasa reseptif dan bahasa produktif secara memadai. Namun demikian penguasaan akan perbendaharaan kosakata masih terbatas namun terus berkembang dengan cepat dan pesat seiring pertumbungan dan perkemabngan usianya. Tahap selanjutnya anak memasuki usai perkembangan bahasa sekolah dasar yang mulai dikenalkan bahasa tulis atau keaksaraan.

Landasan dasar kognitif pemerolehan bahasa anak menurut Lindfors (dalam Tarigan, 1988:7) meliputi 3 hal yaitu: (a) perkembangan semantik anak, (b) perkembangan sintaksis permulaan 9yang merupakan bahasa tuturan/ujaran gabungan permulaan), (c) penggunaan aktif anak sejenis siasat belajar atau gaya belajar. Pemerolehan bahasa anak-anak dapat dikatakan mempunyai ciri-ciri kesinambungan, memiliki suatu rangkaian kesatuan yang bergerak dari ucapan satu kata sederhana menuju gabungan kata lebih rumit (sintaksis). Jika kita beranggapan bahwa kegunaan fungsional tangisan sebagai awal dari kompetensi komunikatif, maka ucapanucapan kata tunggal yang biasanya sangat radiosinkratik atau sangat aneh (misalnya "mam" untuk menunjukkan kata "makan") menandai tahap pertama yang dapat dan mudah dibedakan perkembangan bahasa formal. Bergerak ke arah tahap yang melebihi tahap awal, anak selanjutnya menghadapi tugas-tugas perkembangan yang berkaitan dengan fonologi, morfologi, sintaksis, dan semantik (Gracia dalam Tarigan dalam Djuwarijah, 2017: 27-28).

Menurut Widdosson dan Suhendar, komunikasi dibagi menjadi dua yaitu komunikasi reseptif yang terdiri atas menyimak dan membaca, dan komunikasi produktif terdiri atas berbicara dan menulis. Andini menjelaskan bahasa reseptif adalah kemampuan mendengar, memahami dan menguraikan suatu pesan sehingga dapat dimengerti oleh orang lain sebagai penerima pesan, selanjutnya Sutjihati Somantri menjelaskan bahwa bahasa reseptif adalah kecakapan menerima dan memahami bahasa. Dalam Kamus Besar Bahasa Indonesia, bahasa reseptif adalah kemampuan menerima informasi baik melalui penglihatan maupun pendengaran, sehingga anak yang memiliki kemampuan untuk berbahasa reseptif adalah mereka yang mengerti apa yang dilihat dan dengar.

Beragam faktor penyebab anak mengalami speechdelay namun secara umum adalah rendahnya tingkat kecerdasan anak sehingga anak kurang maksimal dalam menyerap informasi dan mengembalikannya dalam bentuk berbahasa. Kondisi orang tua yang masih sering menggunakan bahasa bayi ketika berkomunkasi dengan anaknya juga dapat sebagai faktor menunjang keterlambatan berbahasa karena anak menjadi kurang memiliki motivasi untuk belajar berbahasa sesuai dengan tahap perkembangannya. Penggunaan bahasa asing di rumah yang bukan merupakan bahasa ibu dapat juga menghambat kemampuan berbahasanya. Contoh lain dalam sebuah kasus yang sering dijumpai adalah banyak orangtua yang membiarkan anaknya menonton televisi tanpa mengomuniksikan siaran apa yang mereka lihat. Terlebih lagi ketika anak sudah mulai banyak bertanya dan banyak komentar tentang suatu hal dan justru orangtua menyuruhnya untuk diam bahkan ada yang hingga membentak dan mengatakan anak tersebut cerewet, yang akhirnya tanpa orangtua sadari berdampak pada psikologis anak dengan dia menarik diri dan memilih untuk diam karena takut atau kecewa harapannya dipatahkan. Ketika anak memilih untuk diam maka secara otomatis perkembangan berbahasa anak mulai melemah dan tidak mampu lagi berkembang mengikuti irama perkembangan teman sebanyanya.

Hurlock juga memiliki pandangan dalam hal ini yaitu keterlambatan berbahasa anak terlihat apabila orangtua tidak hanya berbicara kepada anak mereka akan tetapi juga menggunakan variasi kosakata baru yang lebih luas, sehingga anak menyerapnya dan kemampuan berbahasanya akan berkembang dengan pesat. Selanjutnya Hurlock menambahkan faktor lain penyebab terlambat bicara adalah intelegensi, jenis disiplin (pola asuh), posisi urutan dalam keluarga, besar/banyaknya 
keluarga, status sosial ekonomi keluarga, ras, bilingual (berbahasa dua), dan jenis kelamin (Hurlock, 2006:114-115). Selain itu faktor internal lain diantaranya (a) gangguan kefasihan (fluency disoder) ditandai dengan kegagapan, pengulangan kata-kata, latah, atau memperpanjang bunyi, dan kata tertentu. Gangguan ini misalnya menambahkan bunyi "oh", mengganti kalimat (seperti 'mama pergi pergi'-'mama ke pasar') disini terlihat pengulangan kata "mama" hanya untuk mengucapkan kalimat "mama pergi ke pasar", mengulang frasa misalnya 'aku mau, aku mau, aku mau pulang' pada kalimat ini frasa "aku mau" mengalami pengulangan, mengulangi suatu huruf diawal kata misalnya 'a-a-a-aku mau mimik cucu'. Gangguan-gangguan jenis ini akan hilang seiring dengan bertambahnya usia dan perkembangan anak. Namun dapat juga gangguan ini terus bertahan hingga anak dewasa dan akan menghambat interaksi sosialnya terutama 'gagap'. (b) gangguan artikulasi. Proses artikulasi bunyi melibatkan organ bicara seperti lidah, gigi, bibir, dan palatal (langit-langit). Adanya gangguan artiklasi bisa disebabkan oleh kanker mulut dan tenggorokan, kecelakaan, bawaan lahir (seperti celah bibir), atau faktor lain yang mengakibatkan rusaknya organ bicara. Gangguan artikulasi menyebabkan permasalahan dalam melafalkan bunyi secara benar, misalnya bunyi 'b' menjadi 'w' kata "rambut" dilafalkan "wambut" atau 'wamwut", pelafalan 'tsutsu' atau 'cucu' untuk kata "susu". Gangguan artikulasi ini ketika dialami masa kanak-kanak masih dapat dimaklumi namun ketika telah masuk usia sekolah maka akan mulai menimbulkan masalah terutama pada psikologis anak yang akan menjadi bahan tertawaan temantemannya dan akan menjadi parah jika tetap berlangsung hingga dewasa. (c) gangguan suara yang meliputi gangguan nada, gangguan kualitas bunyi, dan gangguan kenyaringan. Gangguan ini berupa kemonotonan nada, parau, serak, bunyi yang terlalu rendah atau terlalu tinggi, atau kualitas bunyi nasal. Pada gangguan ini disebabkan oleh kecelakaan, kerusakan atau penyakit pada tenggorokan. Spasmodic dysphonia adalah gangguan suara yang diakibatkan kejangnya pita suara sehingga mengganggu alian udara pada pita suara yang berakibat menghasilkan bunyi tersendat, gemetar, suara merintih. Kejang pada pita suara juga dapat menyebabkan Aphonia (hilangnya suara), puberphonia (rentang suara yang sangat tinggi) dan Dysphonia (penurunan kualitas suara) (Subiyantoro, 2013:98)

Metode pembelajaran dan pemberian terapi yang efektif dan efisien diharapakan mampu memperbaiki gangguan speechdelay pada anak terutama gangguan yang bersifat ringan dan sedang akan dapat disembuhkan, gangguang yang dipengaruhi oleh pola asuh, posisi dalam keluarga, keluarga besar, kurangnya perhatian orangtua, dan kurangnya stimulasi. Selain terapi wicara yang dilakukan oleh tenaga ahli atau terapis, memberian metode pembelajaran yang tepat di sekolah dapat membantu anak-anak yang mengalami gangguan speechdelay level ringan dan sedang. Ada banyak metode pembelajaran untuk anak usia dini dalam proses pembelajaran yaitu metode bercerita, bercakap-cakap, tanya jawab, karya wisata, demonstrasi, bermain peran, eksperimen, proyek, dan pemberian tugas. Metode ini digunakan berdasarkan kebutuhan dalam pembelajaran. Pemilihan dan penggunaan metode yang tepat akan mampu menghantarkan tujuan pembelajaran secara optimal. Beberpa metode yang digunakan dalam proses pembelajaran untuk anak berkebutuhan khusus, yaitu (a) communication merupakan proses interaksi yang melibatkan komunikator dan komunikan sehingga diharapkan metode ini dalam menyertakan anak untuk berperan aktif dalam berbahasa verbal maupun non verbal, reseptif maupun produktif, (b) task analisis dilakukan untuk mendeskripsikan tugas-tugas yang harus dilakukan dalam indikator kompetensi sebagai tolok ukur ketercapaiannya, (c) direct instruction merupakan metode pembelajaran yang menggunakan pendekatan secara bertahap dan terstruktur dari yang mudah hingga yang susah, dari yang sederhana hingga komplek, dari yang dekat hingga yang jauh, (d) Prompts merupakan setiap bantuan yang diberikan kepada anak untuk menghasilkan respon yang benar. Prompts diberikan dalam bentuk informasi penjelas atau bantuan yang memudahkan peserta didik dalam memahami instruksi dari pendidik. Ada lima jenis prompts yaitu verbal prompts, modelling, gertural prompts, physial prompts, dan peer tutorial. (e) cooperative Learning yaitu 
metode pembelajaran yang dilakukan secara berkelompok dalam menyelesaikan sebuah tugas. (smart, 2010:103)

Menurut Hurlock, seorang anak dikatakan terlambat bicara apabila tingkat perkembangan bicaranya berada dibawah tingkat kualitas perkembangan bicara seusianya yang dapat diketahui dari ketepatan penggunaannya. Sebagai contoh ketika bermain bersama dengan menggunakan bahasa "ibu" dia masih menggunakan bahasa bayinya. Ditambahkan oleh Papilia bahwa anak yang terlambat berbicara adalah anak yang ketika berusia 2 tahun memiliki kecenderungan salah dalam mengucapkan kata, pada usia 3 tahun memiliki perbendaharaan kata yang minim serta ketika usia 5 tahun masih susah dalam menamai sebuah obyek. Sebagai contoh; ketika anak menyebut kata "mobil" dan ia masih menganggap bahwa mobil itu adalah sebuah mainan dan bukan sebuah transportaasi, maka anak tersebut dapat dikatakan mengalami keterlambatan. Mc. Laughlin dalam Journal of American Familly Doctor, vol. 10 no. 83 tahun 2011 hal 1184 dengan judul artikel "Speech and Language Delay in Children" menjelaskan dalam bentuk tabel tentang "Development Milestones for Speech and Language Children" untuk kategori anak usia 4 tahun kemampuan bahasa ekspresifnya anak mulai mengerti lima makna kata yang diucapkannya, mengetahui dan mampu membedakan empat macam warna dan dapat mengungkapkan keinginan dengan bahasa yang telah dimengerti oleh orang sekitarnya.

Diantara ciri anak yang mengalami speechdelay adalah untuk anak usia 3 tahun belum mengerti kata depan atau tindakan yang dilakukan oleh orang dewasa disekitarnya dan tidak mengikuti arahan dua perintah dari orang dewasa serta dalam bahasa ekspresifnya menggunakan kosakata yang kurang dari 200 kata, ketika menginginkan sesuatu dia tidak menyebut nama benda atau obyek dan mengulangi frasa dalam menanggapi pertanyaan (ekolalia) atau yang lebih sering disebut dengan "membeo". Ciri yang lainnya adalah pada usia berapapun anak mengalami kemunduran dalam berbicara dan berbahasa dari yang dimiliki sebelumnya.

Dari data yang penulis kumpulkan berupa 3 kasus pada anak yang terdapat di biMBA AIUEO sebagai contoh dalam perkembangan bahasa anak yang mengalami gangguan speechdelay bahwa ketiga obyek tersebut mengalami speechdelay dikarenakan faktor jenis displin (pola asuh) yang dari orangtua yang tidak mereka sengaja telah menyebabkan perkembangan bahasa anak mereka sendiri terhambat yaitu dengan mereka lebih sibuk pada pekerjaan masing-masing kurang perhatian kepada anaknya dalam hal mengajaknya berkomunikasi. Orangtua lebih memilih mempercayakan anak mereka kepada asisten rumah tangga atau pembantu dan gadget. Selain itu adanya faktor internal kelainan pada tubuh anak yaitu gangguan pendengaran hingga menyebabkan anak menjadi lambat berbahasa.

Kasus yang dialami VV termasuk jenis specific Language Impairmen yang disebabkan oleh pola asuh dari orang tuanya. VV lebih banyak menghabiskan waktu dengan gadgetnya dan orangtuanya jarang mengajaknya berinteraksi langsung secara intensif. Sehingga interaksi hanya satu arah sehingga kemampuan berbahasanya kurang terstimulasi. Terapi yang diberikan kepada VV adalah terapi wicara dan pijat neuro (syaraf) secara intensif. Sedangkan kasus yang dialami CY termasuk jenis Speech and Language Expresive Disorder yaitu anak mengalami gangguan pada ekspresi bahasa yang disebabkan adanya gangguan otot syaraf pendengaran hingga mengakibatkan kurangnya bunyi-bunyi yang didengar CY sehingga kemampuan untuk mengekspresikan yang terjadi dan keinginannya dalam bentuk verbal kurang maksimal, kemampuan penguasaan kosakatanya juga masih minimalis. Terapi yang diberikan kepada CY ini adalah terapi pendengaran agar dia mampu mendengar bunyi-bunyi dari luar secara normal. Dapat pula diberikan alat bantu jika kondisi CY sangat membutuhkan itu. Adapun kasus yang dialami AA termasuk jenis Specific Language Impairment yaitu gangguan bahasa dikarenakan adanya gangguan dari perkembangannya sendiri yang disebabkan oleh kurangnya interaksi sosial anak. Kesibukan orangtua menjadi faktor penyebabnya dan gadget sebagai pelarian dari AA. Terapi yang diberikan secara medis atau non medis tidak ada karena gangguan yang dialami AA ini lebih 
dikarenakan pada kurangnya interaksi komunikasi dengan lingkungan sosial sekitarnya, sehingga yang cocok untuk AA adalah jenis terapi sosial dengan mengajaknya komunikasi secara langsung, memberikannya kesempatan lebih banyak untuk berteman dengan teman-teman sebayanya.

\section{SIMPULAN DAN SARAN}

Kesimpulan dari artitkel ini adalah bahwa yang dimaksud dengan gangguan Speechdelay yaitu suatu gangguan keterlambatan berbahasa yang dialami oleh individu terutama anak-anak dari perkembangan pada usai yang semestinya dikarena faktor tertentu. Faktor pemicu terjadi gangguan speechdelay diantaranya jenis kelamin, jenis disiplin (pola asuh), stimulasi, gangguan pendengaran, ras, besarnya jumlah keluarga, urutan atau posisi dalam keluarga, intelegensi, kecelakaan, bilingual, dan gangguan kesehatan lainnya. Gangguan ini bisa bersifat ringan, sedang, dan berat. Untuk kasus kategori sedang dan berat diperlukan penanganan dari tenaga medis dan ahli (terapis). Anak speechdelay secara otomatis mengalami gangguan dalam kemampuan berbahasanya baik itu bahasa reseptif dan bahasa produktif. Ada yang mengalami gangguan pada artikulasinya, penghilangan huruf dalam kata, gangguan kefasihan, dan gangguan suara. Pemilihan metode pembelajaran yang tepat dan secara aktif interaktif dapat membantu menyembuhkan anak speechdelay ringan dan membantu anak speechdelay sedang dan berat untuk lebih menyesuaikan diri tentunya ditambah bantuan terapi dari tenaga ahli.

Keterbatasan dari riset ini adalah jumlah sampel yang di observasi, dan hanya satu aspek bahasa reseptif yang dialami oleh anak gangguan speechdelay belum dikembangkan pada aspek lainnya. Penanganan terhadap anak speechdelay belum dibahas dalam riset yang ditulis dalam artikel ini.

Saran dari artikel ini adalah hendaklah dilanjutkan lagi untuk memperdalam pembahasan kasus ini agar lebih holistik dan dapat lebih general dengan menambah lebih banyak kasus yang diobservasi.

\section{DAFTAR RUJUKAN}

Adini, Alfira Luluk. 2016. Kemampuan Bahasa Reseptif Anak Kelompok A Gugus V Kecamatan Berbah. Jurnal.

Adiwiria, Pien Supinah. 2005. Komunikasi Reseptif dalam Meningkatkan Prestasi Belajar Anak. Jurnal.

Djago Tarigan. 2003. Pendidikan Keterampilan Berbahasa. Jakarta: Universitas Terbuka.

Djuwarijah, Siti. Pemerolehan Bahasa Telegram dan Kalimat Anak Usia Prasekolah dan SD. Jurnal Konstruktivisme, volume 9 nomor 1, 2017:19-36.

Fatimah, Lulu. 2012. Pelaksanaan Pengembangan Kemampuan Bahasa Reseptif dan Bahasa Ekspresi Anak Tunarungu Kelas TK A (Studi Deskripsi di LPATR Pangudi Luhur, Kembangan Jakarta Barat). Jurnal. Jakarta: Perpustakaan Universitas Negeri Jakarta.

Hurlock B., Elizabeth.1978. Perkembangan Anak Jilid 1. Jakarta: Erlangga

Hurlock. 2013. Perkembangan Anak. Terj. Meitsari Tjandra. Jakarta: Erlangga.

Jumaris. 2004. Perkembangan dan Pengembangan Anak Usia Taman Kanak-kanak. Jakarta: PT. Gramedia Widiasarana Indonesia.

Khoiriyah, et.al. 2016. Model Pengembangan Kecakapan Berbahasa Anak yang Terlambat Berbicara (Speechdelay). Jurnal. Banda Aceh: Perpustakaan Universitas Syaih Kuala.

Papalia, E.D. 2004. Human Development:Perkembangan Manusia. Jakarta: Salemba Humanika.

Peraturan Menteri Pendidikan dan Kebudayaan nomor 137 Tahun 2014 tentang Standar Nasional Pendidikan Anak Usia Dini.

Peraturan Menteri Pendidikan dan Kebudayaan nomor 146 Tahun 2014 tentang Kurikulum 2013 Pendidikan Anak Usia Dini. 
Ragil Kuning,Retno. 2019. Kemampuan Berbahasa Reseptif Menyimak pada Anak dengan Speechdelay..Skripsi. Surabaya: UIN Sunan Ampel.

Rumini, et.al. 2004. Perkembangan Anak dan Remaja. Jakarta: Rineka Cipta.

Santrock, J.W. 2009. Life Span Development Perkembangan Masa Hidup. Jakarta: Erlangga.

Sari, Sarah Novi Lia, dkk. Angka Kejadian Delayed Speech Disertasi Gangguan Pendengaran pada Anak yang Menjalani Pemeriksaan Pendengaran di Bagian Neurootologi IKTHT-KL RSUP Dr. Moh. Hoesin. Jurnal Kedokteran dan Kesehatan, volume 2 nomor 1, Januari 2015: 121-127.

Subyantoro. 2013. Gangguan Berbahasa: Mengenali untuk Mengantisipasi Sejak Dini. Jogjakarta: Ombak

Tarigan, Henry Guntur. 2008. Menyimak Sebagai Suatu Ketrampilan Berbahasa. Bandung: Angkasa

Tiel, Julia Maria Van. 2008. Pendidikan Anakku Terlambat Berbicara. Jakarta Timur: Perdana Media.

\section{AUTHOR}

Dr. Jauharoti Alfin, M.Si, Dosen UIN Sunan Ampel Surabaya

Ratna Pangastuti, M.Pd.I Dosen UIN Sunan Ampel Surabaya 